\title{
Evaluation of tree frog tracking methods using Phyllomedusa trinitatis (Anura: Phyllomedusidae)
}

\author{
Eleanor H. Z. Gourevitch and J. Roger Downie
}

School of Life Sciences, Graham Kerr Building, University of Glasgow. Glasgow G12 8QQ, United Kingdom. E-mail: ehzgourevitch@gmail.com.

\begin{abstract}
Evaluation of tree frog tracking methods using Phyllomedusa trinitatis (Anura: Phyllomedusidae). Investigating the behaviors of small, inconspicuous and cryptic animals can be helped by tracking their movements. The effectiveness of different tracking methods can be very dependent on behavior and ecology; radio-telemetry and thread bobbins have been widely used over a range of environments and taxa, but each presents problems. Phyllomedusa trinitatis is a tree frog found in Trinidad and Venezuela and has mostly been studied for its nest building and breeding behavior, but little is known about its behavior away from breeding ponds. This study aimed to identify the strengths and weaknesses, including impacts on the welfare of these frogs, of different tracking methods, thread bobbins and radio-telemetry, when used to track them in a dense rainforest environment. A pilot study found that fluorescent dyes were unsuitable for this species. Individuals were tested in laboratory conditions to determine the application time for each tracker and to test on this species the tracker $10 \%$ weight rule. The rule was found to be too restrictive for this frog; trackers up to $15 \%$ of body weight were used with no significant impacts on distances travelled. Frogs became lethargic when bearing trackers longer than two days, so we limited tracking in the field to one overnight period. Of the 26 frogs tracked in the field (nine radio-tags, 17 bobbins), 16 were successful (six radio-tags, 10 bobbins) and six untracked frogs were found in the field during the day as controls. Bobbins were cheaper and allowed visualization of the detailed path taken, including substrates used, but caused more bruising due to entanglement, and individuals tracked with this method were less likely to return on following nights to the breeding ponds. Radio-tags had no threat of entanglement but were much more expensive and the signal was interrupted by the dense vegetation preventing some individuals from being found. There were no significant differences in the distances travelled by tracked or control frogs, from which we infer that these tracking methods did not impact significantly on movement. It appears that neither of these tracking methods work perfectly for Phyllomedusa in a densely vegetated environment, and that both incur welfare problems. Our study emphasizes the need to test out tracking methods on each species in each habitat.
\end{abstract}

Keywords: fluorescent powder, movements, radio-tags, radio telemetry, thread bobbins.

Received 21 March 2018

Accepted 18 November 2018

Distributed December 2018 


\section{Resumo}

Avaliação de métodos de rastreamento de pererecas usando Phyllomedusa trinitatis (Anura: Phyllomedusidae). A investigação do comportamento de animais pequenos, inconspícuos e crípticos pode ser auxiliada pelo rastreamento de seus movimentos. A eficiência de diferentes métodos de rastreamento pode ser muito dependente de seu comportamento e ecologia; rádiotelemetria e bobinas de rastreamento têm sido largamente utilizadas com uma variedade de ambientes e táxons, mas cada uma dessas técnicas apresenta problemas. Phyllomedusa trinitatis é uma perereca encontrada em Trinidad e na Venezuela e tem sido estudada principalmente no que se refere a seu comportamento reprodutivo e de construção de ninhos, mas pouco se sabe sobre seu comportamento longe das lagoas reprodutivas. Este estudo teve como objetivo identificar vantagens e desvantagens de diferentes métodos de rastreamento (bobinas de rastreamento e rádio-telemetria), incluindo impactos no bem-estar desses anuros, quando usados para rastreá-los em um ambiente de floresta pluvial densa. Um estudo-piloto mostrou de tintas fluorescentes foram inadequadas para essa espécie. Indivíduos werforam testados em condições laboratoriais para determinar o tempo de aplicação de cada rastreador e para testar nessa espécie a regra dos $10 \%$ do peso. A regra mostrou-se muito restritiva para essa perereca; rastreadores com até $15 \%$ do peso corpóreo foram usados sem impactos significativos sobre a distância percorrida. Os animais tornaram-se letárgicos quando portavam rastreadores por mais de dois dias, de forma que limitamos o rastreamento no campo a um período de uma noite. Dos 26 indivíduos rastreados no campo (nove com radiotransmissores, $17 \mathrm{com}$ bobinas), 16 foram bem-sucedidos (seis com radiotransmissores, 10 com bobinas) e seis indivíduos não-rastreados foram encontrados no campo durante o dia como controles. As bobinas são mais baratas e permitem a visualização detalhada do caminho percorrido, incluindo os substratos utilizados, mas causam mais injúrias devido ao entrelaçamento, e os indivíduos rastreados com este método eram menos propensos a retornar nas noites seguintes para as lagoas de reprodução. Os radiotransmissores não ofereciam a ameaça de emaranhamento, mas são muito mais caros, e o sinal era interrompido pela densa vegetação, impedindo que alguns indivíduos fossem encontrados. Não houve diferenças significativas nas distâncias percorridas por indivíduos rastreados e animaiscontrole, do que inferimos que esses métodos de rastreamento não tiveram impacto significativo sobre o movimento. Parece que nenhum desses métodos de rastreamento funciona perfeitamente para Phyllomedusa em um ambiente com vegetação densa e que ambos geram problemas de bem-estar. Nosso estudo enfatiza a necessidade de testar métodos de rastreamento para cada espécie em cada habitat.

Palavras-chave: bobinas de rastreamento, movimentos, pó fluorescente, rádio-telemetria, radiotransmissores.

\section{Introduction}

The movements and behaviors of smallbodied animals are of great interest as they can provide important information regarding their ecology. Where animals cannot be observed continuously, various kinds of tracking device can be used. Tracking devices need to be small, lightweight, inconspicuous, and to cause minimal stress to the animal so as not to interfere with natural behaviors. Several methods have been used over time with a variety of success, including radio-telemetry (Mullican 1988,
Gourret et al. 2011, Kays et al. 2011), thread bobbins (Waddell et al. 2016), and fluorescent powder (Rittenhouse et al. 2006, Orlofske et al. 2009). Due to the wide range of taxa and environments where these tracking methods are used, it is not possible for any technique to be effective in all environments; therefore it is important for them to be tested to determine the limits of their use and effectiveness.

Amphibians are mainly small, nocturnal, inconspicuous, silent most of the time, and they spend much of each day inactive. Amphibian behavior outwith times of reproductive activity 
remains poorly known, except for a few species (Wells 2007). What they do when absent from breeding sites, how far they travel, what behaviors they exhibit, what habitats they utilize: all these features are under-researched. Marks of various sorts used to identify individuals, and tracking devices for following where individuals go can provide a solution to some of these problems. For reviews, see Ferner (2010) on marking and trailing methods; Madison et al. (2010) on radio telemetry. Laughlin et al. (2017) have reported that camera traps aimed at studying arboreal mammals can provide some limited information on tree frogs too. However, as Ferner (2010) notes, there is no general or ideal method: the procedures likely to work best will vary with the species, the habitat and the objectives of the study.

Phyllomedusa trinitatis, known as the Trinidad Leaf Frog or the Monkey Tree Frog, is found in Trinidad and Venezuela, but is absent from Tobago (Murphy 1997). It occupies many different habitats, including lowland rainforest, cloud forest, deciduous forest and savannah, both within and on the periphery, all of which are present within Trinidad. The research previously conducted on $P$. trinitatis behavior has centered on nest building and breeding (Kenny 1966, Downie et al. 2013). Phyllomedusa trinitatis possess a set of stable, individually variable ventral marks that allow the identification of individuals (Smith and Downie, pers. com.). With the aid of these marks, it has been possible to establish the patterns of breeding site attendance both by males and females, with some males attending very frequently and others only occasionally (Gourevitch and Downie, pers. obs.). However, little is known of the behavior of this species away from breeding ponds.

This study tested the effectiveness of different methods of tracking the tree frog $P$. trinitatis. A pilot study (2015: see Appendix I) used fluorescent powder to mark the frogs, and assessed procedures for attaching radio-tags and thread bobbins. Since the fluorescent dyes appeared to have harmful effects in this species, the full study (2016) focused on radio- tags and thread bobbins. We began with laboratory-based observations on how long frogs behaved normally with the devices attached. This was followed by a field study which aimed to assess the comparative strengths and weaknesses of the two devices, including effects on the welfare of the frogs, and to find what these tracking devices could tell us about the behavior of these frogs once they left their breeding ponds. This is the first study to report on the use of thread bobbins to track tree frogs.

\section{Materials and Methods}

\section{Study Site}

The William Beebe Research Centre (Verdant Vale, Arima Valley; 1041'33.2" N, 61¹7'22.7" $\mathrm{W})$ in Trinidad's Northern Range mountains houses a substantial population of $P$. trinitatis. The grounds of the Centre include three sets of artificial concrete ponds used as breeding sites by this and several other frog species (Figure 1). All the ponds are surrounded by vegetation, some of which overhangs the water at various heights, on which males congregate from about 17:00 to 03:00 h. Ponds 1 and 2 are very close to the Centre's buildings, Pond 3 is more isolated, and all the ponds are subject to noise from the nearby quarry. Beyond the Centre's low boundary wall there is dense secondary tropical forest with no nearby standing water. Pond 3 is located within the forest.

On nights during the rainy season, June to December, $P$. trinitatis adults can be located perched on branches around and over the ponds. Although the males emit quiet, short, irregular calls, it is difficult to locate them by call alone, and much easier with the aid of torches.

\section{Preparation of Tracking Devices}

Tracking devices were prepared before the night of attachment. Tracking devices were attached to a harness made out of $100 \%$ cotton 


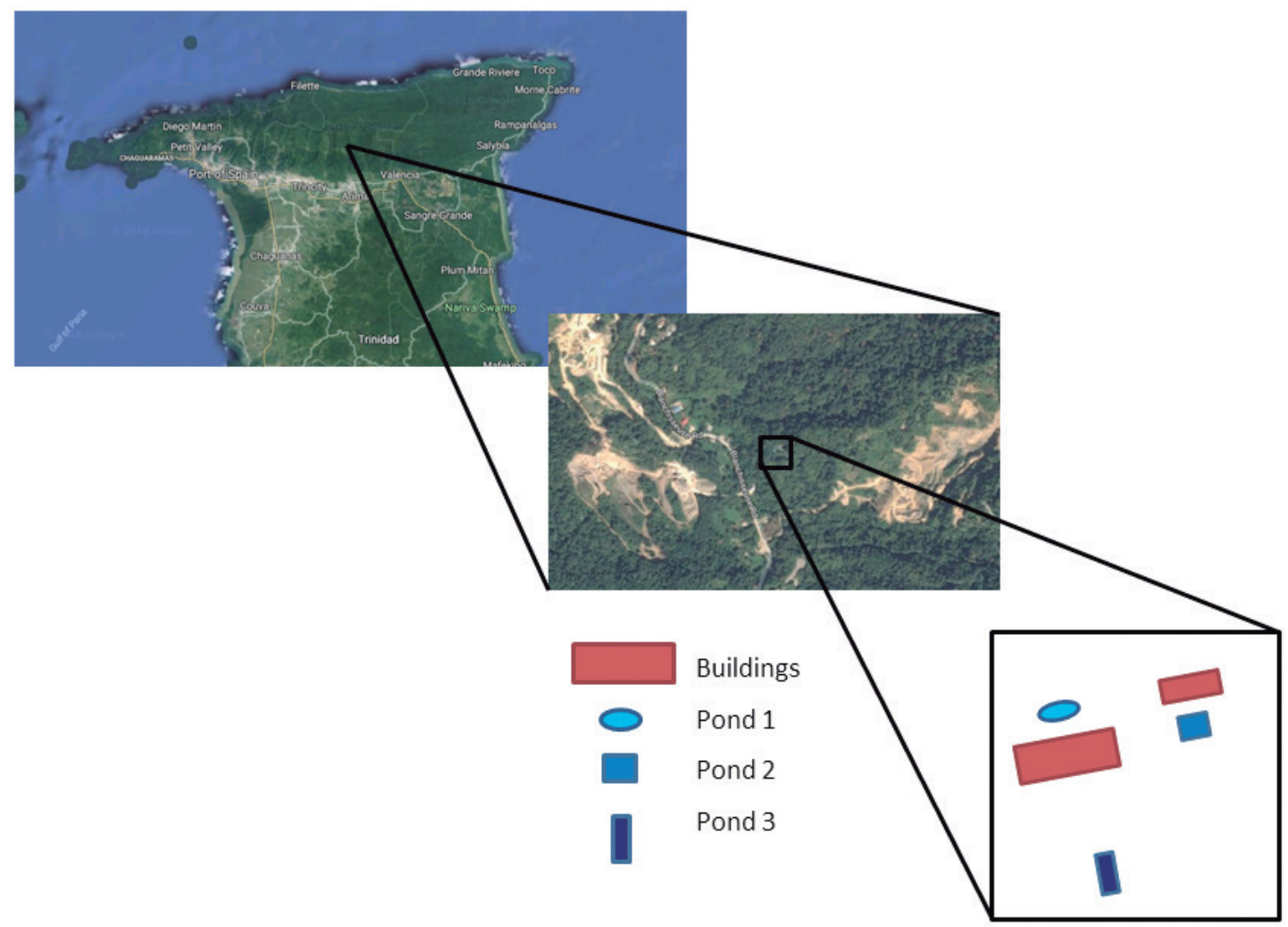

Figure 1. A diagram showing the position of the study site within Trinidad's Northern mountain range, its proximity to nearby quarries and the approximate positions of the ponds relative to the William Beebe Tropical Research Centre buildings based on Google Maps images and measurements taken on site. Pond 1 is $6 \times 4 \mathrm{~m}$, Pond 2 is $3 \times 2 \mathrm{~m}$, and Pond 3 is $5 \times 3 \mathrm{~m}$. The distance between Ponds 1 and 2 is $36 \mathrm{~m}$ and between 1 and 3 is $60 \mathrm{~m}$ (all distances to the nearest meter).

thread which had non-toxic plastic beads attached (the Beadroom F458-11) as used in previous studies (Muths 2003), which provided a larger surface area and had the ability to roll, moving with the frog and reducing damage (Long et al. 2010, Gourret et al. 2011). This was formed into a loop and tied with a bowline knot to allow the harness to be tightened to fit the frog's waist.

Bobbins.-The bobbins were $2 \mathrm{~g}$ nylon thread cocoon bobbins, approx. 130 meters in length (Danfield Ltd: Nm140/2 P4 Nylon; Waddell et al. 2016) (Figure 2A). The use of cocoon bobbins reduces the chance of snagging or entanglement by unraveling from the center. The bobbins were wrapped in a cling film layer and then a duct tape layer (which still allowed the thread to be drawn out unhindered) in order to reduce any water absorption. Only one bobbin harness was used at each pond on each tracking occasion in order to reduce the chances of entanglement.

Radio-tags.-The radio-tags used (see Appendix II: UHF Beacon Transceiver) were $2 \mathrm{~g}$ in mass (Figure 2B). A radio-tag was used instead of a GPS locator as the individuals' movements were too small to be distinguished by a GPS. All radio-tags were fully charged before being deployed and were securely 
attached to the harness. Before each tracking the radio-tags were wrapped in cling film and duct tape in order to reduce any potential water damage; this did not interfere with the signal.

\section{Laboratory Trial of Tracking Devices}

The laboratory trial aimed to assess how the presence of the tracker might affect the behavior of the individuals. Individuals used in the laboratory were all randomly chosen from pond 3 with some repeats. Three tall tanks $(20 \times 30 \times$ $100 \mathrm{~cm}$ ) were set up on the floor of a Centre laboratory, each containing a pool of water on the bottom with tall branches placed inside to encourage climbing, but with no food provided. Each tank had a labeled grid with $4 \mathrm{~cm}^{2}$ squares drawn on to one side. This trial was carried out with four groups of three frogs. In addition, three individuals were kept in the tanks for a longer period, one with a bobbin tracker attached, one with a radio-tag attached and one control. They were kept in these conditions for three consecutive days in order to assess the impact of trackers on natural behaviors.

Individuals were placed singly into the center of each of the tanks for two days. Each frog was weighed once a day and its position recorded every $30 \mathrm{~min}$ from 22:00 to 02:00 h. On the first day the individuals were studied with no trackers. On the second day, two of the individuals were fitted with a pre-weighed harness and tracker (one a bobbin, the other a radio-tag) and one frog left as a control. All individuals were handled before being returned to the tanks and their positions recorded as before. The scoring for distance moved was calculated as follows; every horizontal and vertical grid square was a length of $4 \mathrm{~cm}$. For instance, if a frog moved from A3 to D7 the horizontal movement from A to D would consist of three squares of movement and would therefore be $12 \mathrm{~cm}$. The vertical movement from three to seven would be four squares and therefore would be $16 \mathrm{~cm}$. In total the frog would have moved $12+16=28 \mathrm{~cm}$.
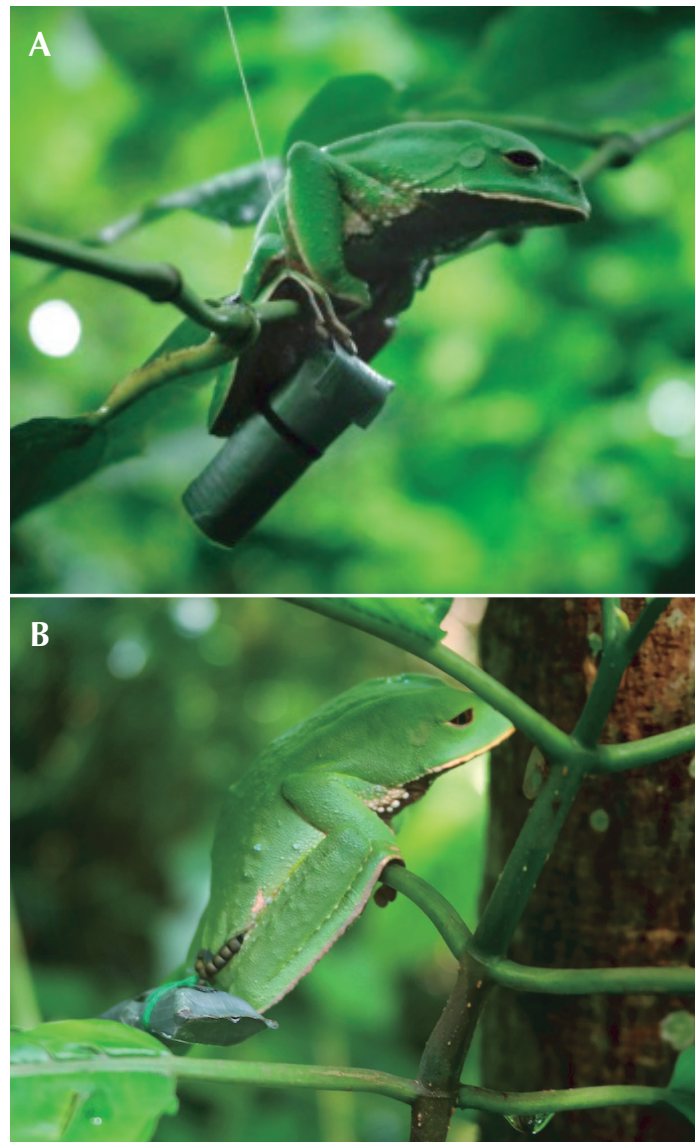

Figure 2. Phyllomedusa trinitatis bearing a bobbin (A) and a radio-tag $(\mathbf{B})$.

\section{Field Observations Using Tracking Devices}

Frogs were chosen randomly for tracking, always from ponds 1 and 2, and no frog was tracked more than once. The starting location of each individual was marked with a clip, the frog removed, ventral marks photographed, weight measured to $0.1 \mathrm{~g}$ using a spring balance, snoutvent lenght (SVL) measured to the nearest $0.1 \mathrm{~mm}$ using calipers and the tracking device, its weight and harness weight recorded. The tracker was then attached and secured, before the frog was returned to its original position in the vegetation. 
The starting position of the frog was recorded by measuring the distance to a predetermined $\mathrm{X}$-axis and a $\mathrm{Y}$-axis using a laser rangefinder (Bosch GLM50 $50 \mathrm{~m}$ laser, range: 0.05-50 m, accuracy: typically $\pm 1.5 \mathrm{~mm}$, measurement time: typically $<0.5 \mathrm{~s}$ ). The height from ground was measured to the nearest $5 \mathrm{~cm}$ using a marked pole; height from water was not used as only Ponds 1 and 3 have drainage pipes, so the level varied within one of the ponds.

The laboratory study showed that after several days with a tracker attached frogs showed lethargy and bruising, therefore tracker use was limited to less than 24 hours; individuals were tracked 12 hours after the tracker was attached. Once located, the tracker was removed, the frog examined and photographed before being returned to its location. Tracking was considered to be successful if the frog was tracked, found in a quiescent state and safely released.

Bobbin.-The bobbin left a path of thread, which was followed during tracking. To obtain the true distance that the individuals had travelled, the length of the thread released was measured. The substrates used to travel and rest upon were also recorded. This continued until the frog was found, when its height from the ground was measured; it was then released from the harness, checked for any signs of bruising, photographed and replaced in its resting position.

Radio-tag.- The radio-tag was located using a Yagi antenna and radio receiver (see Appendix II). The tracking began from the starting location of the frog; the antenna was swept from left to right. When the strongest direction of the signal was emitted, by a noise and visual display from the receiver, this path was followed until the frog was located. Once the frog with the radio-tracker was located, the height from the ground was measured, the harness was immediately removed from the frog's waist and the frog was checked for signs of bruising, photographed and replaced at its resting site. To record the ending point of the frog, the distances to the ' $x$ axis' and the ' $y$ axis' of the starting pond were measured and the distance between the start and end positions were plotted and measured using ImageJ.

\section{Re-appearance of Tracked Frogs}

To assess any possible longer-term effects of the tracking devices on the frogs, each night all frogs present on Ponds 1 and 2 were located and photographed. These photographs were carefully checked to determine if a tracked frog was present and the number of days until their re-appearance was recorded.

\section{Quiescent Frogs Located in the Field}

During the day the areas surrounding the ponds were searched for quiescent individuals. Any individuals found had their ventral patches photographed for later identification and resting positions were measured in the same way as for the tracked individuals and were plotted onto a map of the closest pond. These individuals were used as a control for the tracked individuals in order to determine if the tracker had a significant impact on the distance travelled or the quiescent resting position of the individuals. Since these individuals did not have a starting position, their distance travelled from the pond was measured using their minimum distance from the closest pond edge, as this was comparable to all tracked individuals. Because their ventral markings were recorded, it was possible to determine if they visited the ponds the previous or on subsequent nights.

\section{Analyses}

All statistical analysis were conducted using R 3.3.1 ( $\mathrm{R}$ Core Team 2016). A repeated measures ANOVA was used in order to model the distances moved within the laboratory tanks by control individuals and individuals wearing bobbins or radio-tags; tank was modeled as a repeat predictor and SVL as an independent predictor. A mixed effect model was used to model the field tracking, including pond as a mixed effect. 
Evaluation of tree frog tracking methods using Phyllomedusa trinitatis

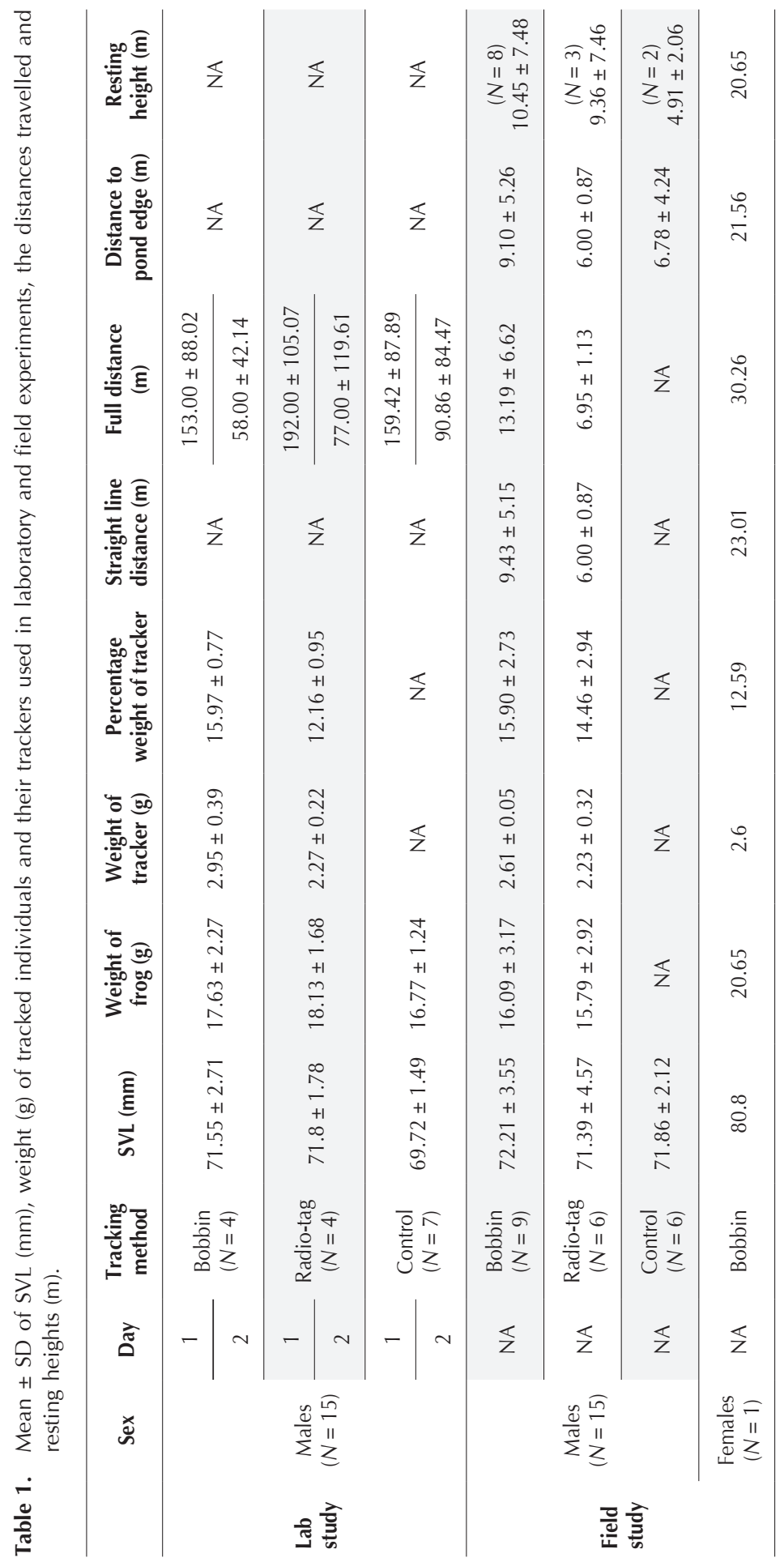




\section{Results}

Table 1 shows the weights of individuals and trackers, the SVLs of the individuals, and the true distance travelled for different tracking methods used in both the laboratory and field studies, and the straight line distance travelled, the distance from the pond edge and the height from the ground from the field observations.

\section{Laboratory Trial}

Frog SVL showed no significant relationship with the distance moved $(\mathrm{F}=1.34, d f=2, p=$ 0.28). The type of treatment (bobbin, $N=4$; radio-tag, $N=4$; or control, $N=6$ ) also had no significant relationship with the distance moved ( $\mathrm{F}=0.23, d f=2, p=0.79)$. The percentage weight of the tracker did not have a significant relationship with distance travelled $(\mathrm{F}=0.014$, $d f=1, p=0.91)$. Treatment, excluding control, also did not have a significant relationship with the distance travelled $(\mathrm{F}=0.36, d f=1, p=0.56)$.

During day 1 of the trial, individuals did not have a tracker attached and individuals were found to move on average $88 \mathrm{~cm}$ further than on day 2, a significant difference $(\mathrm{t}=-2.85, d f=28$, $p=0.008)$. In the three day trial, individuals showed lethargy and bruising from the trackers.

\section{Field Comparison of Tracking Devices}

In total 26 frogs were tracked. The numbers of successful and unsuccessful tracking attempts are shown in Table 2 along with the numbers of returning individuals. The bobbin method was unsuccessful when the thread became wet, causing it to swell and restricting release from the cocoon, or if individuals repeated the same path many times, potentially causing a knot to form, both of which resulted in tangling. This restricted the frog's movements, sometimes

Table 2. Number of successful and unsuccessful field trackings and number of individuals that returned one day after the tracking event, and at all during the survey, and the minimum and maximum days taken for individuals to return.

\begin{tabular}{|c|c|c|c|c|c|c|c|c|}
\hline \multirow[t]{2}{*}{$\begin{array}{l}\text { Tracking } \\
\text { method }\end{array}$} & \multicolumn{2}{|c|}{$\begin{array}{l}\text { Successful } \\
(N=16)\end{array}$} & \multicolumn{2}{|c|}{$\begin{array}{l}\text { Unsuccessful } \\
\qquad(N=10)\end{array}$} & \multirow{2}{*}{$\begin{array}{c}\text { Success } \\
(\%)\end{array}$} & \multicolumn{3}{|c|}{$\begin{array}{c}\text { Return to breeding } \\
\text { ponds }\end{array}$} \\
\hline & Male & Female & Male & Female & & $\begin{array}{l}1 \text { day } \\
\text { after }\end{array}$ & $\begin{array}{l}\text { During } \\
\text { survey }\end{array}$ & $\begin{array}{c}\text { Min:max } \\
\text { days }\end{array}$ \\
\hline $\begin{array}{l}\text { Bobbin } \\
(N=17)\end{array}$ & 9 & 1 & 7 & 0 & 59 & 0 & 4 & $4: 16$ \\
\hline $\begin{array}{l}\text { Radio-tag } \\
(N=9)\end{array}$ & 6 & 0 & 3 & 0 & 67 & 5 & 6 & $1: 8$ \\
\hline $\begin{array}{l}\text { Control } \\
(N=6)\end{array}$ & $\mathrm{NA}$ & NA & NA & NA & NA & 6 & 6 & $1: 1$ \\
\hline
\end{tabular}

Table 3. The mean percentages $( \pm \mathrm{SD}$ ) of each type of substrate that was used for travelling or to come to rest on by individuals successfully tracked using bobbins $(N=9)$.

\begin{tabular}{lcccc}
\hline & \multicolumn{4}{c}{ Percentage of distance travelled on substrate (\%) } \\
\cline { 2 - 5 } & Ground & Shrub & Tree & Manmade \\
\hline When travelling & $29.58 \pm 24.24$ & $51.07 \pm 26.21$ & $20.37 \pm 10.30$ & $12.99 \pm 6.72$ \\
Resting place & 11 & 22 & 67 & - \\
\hline
\end{tabular}


bruising the frog's waist, and this was fatal on one occasion. We found no lacerations caused by the harness, even in the cases where a frog became tangled for periods of time, but there was discoloration on almost all occasions that a frog was tracked, even in the laboratory where movement was restricted. The radio-tag method of tracking was only problematic when the individuals moved to high arboreal locations; the signal became distorted and the frog could not be tracked or the frog climbed too high into the trees for tracker recovery.

The straight-line distances moved from the pond edges by successfully tracked (bobbin $N=$ 9 , radio-tag $N=6)$ and control, non-tracked $(N=$ 6) male individuals, were statistically compared (Table 1). The SVL of the frog did not have a significant relationship with the distance travelled from the pond edge ( $\mathrm{F}=0.005, d f=1, p=0.94)$. The treatment had no significant relationship with the distance travelled from the pond edge $(\mathrm{F}=1.63, d f=2, p=0.23)$, but those individuals tracked using a bobbin travelled significantly further than non-tracked or radio-tag tracked individuals $\left(\mathrm{t}=6.82, d f=9, p=4.13 \times 10^{-6}\right)$. Individuals tracked using bobbins travelled the greatest distances but had a much greater variability in the straight distances travelled from the pond edge (mean $9.01 \pm 5.26 \mathrm{~m}$ ) than control individuals $(6.78 \pm 4.24 \mathrm{~m})$ and those tracked using radio-tags $(6.00 \pm 0.87 \mathrm{~m})$.

The mean full distances moved by bobbintracked male individuals were on average 59\% more than the straight- line distances. The full distance moved by the single female frog was 31 $\%$ further than its straight-line distance, which was much further than the straight-line distances moved by males. The tracked individuals used a variety of different surfaces on which to travel, shown in Table 3. All individuals tracked using radio-tags or found quiescent were found resting on the leaves of shrubs, control individuals often flat against the surface, tracked individuals often perching. The number of days before tracked individuals returned to the breeding ponds is shown in Table 2. Not all individuals successfully tracked using the bobbin method returned to the ponds during the survey period, but all those successfully tracked with radio-tags returned at some point during surveying.

\section{Discussion}

This study compared two methods of tracking using the tree frog Phyllomedusa trinitatis (radio-tags and thread bobbins), by analyzing the distances travelled and pathways taken by individuals after leaving their breeding ponds, and by assessing the effects of the trackers on the frogs. The tracker's weight as a percentage of the individual's weight did not have a significant influence on the distance travelled by the frog in the laboratory or field study, but the time that the individuals were kept in captivity had a significant impact on the distance that they moved. Not all field tracking was successful; bobbins presented challenges due to tangling of the thread which restricted movement, causing bruising; the radio-tags were difficult to track in densely forested locations due to signal distortion, and could not be recovered in some cases because of the heights the frogs climbed to. The two tracking methods also provided different amounts of information about the behavior of the individuals; bobbins could show the path travelled which gave information on the full distance moved and the surfaces used when moving. Trackers could have negative effects on the individuals' fitness and welfare; skin bruising occurred in some cases, and tracked individuals took longer than untracked frogs to return to the breeding ponds, possibly affecting their breeding success.

\section{Laboratory Study}

Heyer et al. (1994) recommended that tracking devices should weigh less than $10 \%$ of an individual's weight so as not to interfere with behavior. Trackers used in our study were often more than $15 \%$ (but never as much as $20 \%$ ) of an individual's weight, but tracker weight 
showed no significant effect on the distances travelled either in the laboratory or in the field, suggesting that for this species the $10 \%$ rule may be overcautious. This may be specific to this species; amphibians show a wide range of sizes and weights, many much smaller than $P$. trinitatis. It may also depend on the behavior of the frog: $P$. trinitatis is a slow-moving frog which, in our experience rarely jumps, and this may allow it to tolerate heavier loads than some other species. However, it seems prudent that the tracker should be kept as light as possible, but that the maximum weight used should be specific to the species and be determined by a pilot study.

Individuals with and without trackers attached travelled significantly less on the second day of laboratory trials. This may indicate that for this species extended housing is not beneficial, or that the laboratory conditions in this study were not adequate and that the distance data collected in the laboratory study should be regarded as inconclusive.

\section{Comparison of Tracking Techniques}

Both tracking techniques presented challenges. Bobbins caused bruising and this was fatal on one occasion due to tangling of the thread, an indication that bobbins may not be the appropriate method to track at least this species of tree frog. Radio-tags were difficult to locate in densely forested areas as trees distorted the signal and were difficult to retrieve when individuals came to rest out of reach and this may mean that radiotracking is unreliable in some habitats and for some species. In the case of tree frogs, it is precisely the larger species, which can tolerate the weight of a tracker, that are likely to climb to great heights in the trees, compared to smaller bush-dwelling species.

These have been found to be common issues when tracking other taxa (Dole 1965, Muths 2003, Ferner 2010). We suspect that the threat of entanglement when using the thread bobbin method may be more serious for tree frogs, moving through bushes and up into trees, than for ground dwelling animals. There has been some success using thread bobbins with semiarboreal snakes, but this may be due to their lack of limbs (Waddell et al. 2016). Such problems are likely to become more serious the longer the bobbin tracker is in place, and this may limit the usefulness of the method. We found that fewer bobbin tracked individuals returned to the ponds post tracking than the control individuals or the radio-tagged individuals; this could indicate that the bobbin tracked individuals experienced greater levels of stress and therefore needed more time, or were unable to recover before returning to the breeding ponds to attempt to mate.

Bobbins and radio-tags did not differ in size and weight, or in attachment time, but they did differ greatly in cost, $£ 65 / \mathrm{kg}$ for bobbins (approximately 150 bobbins) and $£ 150$ each for radio-tags (Waddell et al. 2016). Bobbins had the specific advantage of being able to track the exact route taken, including the substrate travelled over by the frog unlike radio-tags which only provided the start and end locations.

In spite of the issues with each of the tracking methods, these techniques allowed individuals to be tracked beyond the breeding ponds, revealing their daytime resting positions, distances moved and paths taken. The one female that was tracked travelled much further than any of the males. As there was no significant relationship found between the size of the individual and the distance travelled this is unlikely to be due to the larger size of the female. The female had just deposited eggs and therefore would be unlikely to return to the breeding ponds until a new batch of eggs had developed. It is likely that males would return the next evening to attempt to mate again, an explanation for why they would travel significantly shorter distances (Gourevitch and Downie pers. obs.).

Previous authors have noted (Rowley and Alford 2007, Ferner 2010) there is no ideal method for tracking amphibians. The best method for any particular study will vary with the species, the habitat and the aims of the study. Our results concur with that conclusion; the 
combination of a humid and densely vegetated environment with an arboreal frog caused issues when using bobbins or radio-tags. Any form of interference with natural behavior may introduce new risks, for instance, increasing the threat of predation due to increased weight (Blomquist and Hunter Jr. 2007).

Bobbins (thread and spool method) and radio-tags (radio-telemetry) have both been successful when used to track herpetofauna, crabs and small mammals in a wide range of environments, from aquatic to desert to rainforest (Taylor and Katahira 1988, Eiler 1995, Key and Woods 1996, Steinwald et al. 2006, Schlacher and Lucrezi 2010, Kays et al. 2011, Waddell et al. 2016). It appears that the issues we experienced using bobbins are common, regardless of the taxa being tracked; many authors have experienced tangling and sometimes fatalities (Key and Woods 1996, Steinwald et al. 2006). The requirements for trackers (small size, low weight, enduring, versatile, adaptable) are many, and the lack of a universally suitable device means that any study is likely to involve compromises in the quality of the data collection and potentially harmful impacts on the animals being tracked. In spite of these issues, a great amount of data has been collected using these methods which have contributed to the knowledge of the behavior of many taxa.

\section{Welfare Issues}

Issues relating to the welfare of amphibians in field studies and in captivity are increasingly discussed (Michaels et al. 2014), and many journals and herpetological organizations have developed ethical codes of practice aimed at ensuring minimal harm to the animals studied (for example, BHS 2017). One hotly-debated topic is the use of toe-clipping as a marking device for frogs (Parris et al. 2010). In our study, we discontinued use of fluorescent dyes and kept tracker use to a maximum of 12 hours as a result of welfare concerns. Nevertheless, some frogs were harmed: use of the tracking devices caused some bruising, and some frogs died during the study, or had their normal behavior altered. In the absence of an entirely harmless tracking device, the use any such method is likely to involve a trade-off between the value of the information obtained and the harm to some animals (Parris et al. 2010).

\section{Acknowledgments}

We thank members of the 2015 and 2016 University of Glasgow Trinidad Expeditions for their help in the field; also Paul Hoskisson, Sarah Brozio, Thomas Burns and Mark Greener for advice. Ronnie Hernandez's knowledge of the area and the animals was vital in the planning and execution of this study. Finally, Nosrat Mirzai for advising upon and demonstrating the radio-tags and associated equipment. Funders of this work included the University of Glasgow Exploration Council, the Thriplow Trust, Dennis Curry's Charitable Trust, Glasgow Natural History Society, Iain McGinniss, the Sir James Miller Trust, the Gilchrist Educational Trust, the Lindeth Charitable Trust and the Youth Activity Fund whose grant allowed purchase of the radiotags. Permits were issued by $\mathrm{Mr}$ Romano Macfarlane (Head of Trinidad Wildlife Division) and Ms. Anna Bandoo to Eleanor Gourevitch to work with $P$. trinitatis at the William Beebe Tropical Field Station.

\section{References}

BHS. 2017. British Herpetological Society: ethical policy and guidelines. Herpetological Bulletin 141: 46-48.

Blaylock, L. A., R. Ruibal, and K. Platt-Aloia. 1976. Skin structure and wiping behavior in phyllomedusine frogs. Copeia 1976: 283-295.

Blomquist, S. M. and M. L. Hunter Jr. 2007. Externally attached radio-transmitters have limited effects on the antipredator behavior and vagility of Rana pipiens and Rana sylvatica. Journal of Herpetology 41: 430-438.

Dole, J. W. 1965. Summer movements of adult leopard frogs, Rana pipiens Schreber, in Northern Michigan. Ecology 46: 236-255. 
Downie, J. R., M. Nokhbatolfoghahai, D. Bruce, J. M. Smith, N. Orthmann-Brask, and I. MacDonald-Allan. 2013. Nest structure, incubation and hatching in the Trinidadian leaf-frog Phyllomedusa trinitatis (Anura: Hylidae). Phyllomedusa 12: 13-32.

Eiler, J. H. 1995. A remote satellite-linked tracking system for studying Pacific Salmon with radio telemetry. Transactions of the American Fisheries Society 124: 184-193.

Ferner, J. W. 2010. Measuring and marking postmetamorphic amphibians. Pp. 123-141 in C. K. Dodd Jr. (ed.), Amphibian Ecology and Conservation: $a$ handbook of techniques. Oxford, New York. Oxford University Press.

Gourret, A., R. A. Alford, and L. Schwarzkopf. 2011. Very small, light dipole harmonic tags for tracking small animals. Herpetological Review 42: 522-525.

Heyer, R. W., M. A. Donnelly, M. Foster, and R. W. McDiarmid. 1994. Supplemental approaches to studying amphibian biodiversity. Pp. 143-182 in W. R. Heyer, M. A. Donnelly, R. W. McDiarmid, L. C. Hayek, and M. S. Foster (eds.), Measuring and Monitoring Biological Diversity. Standard methods for amphibians. Washington D.C. Smithsonian Institution Press.

Kays, R., S. Tilak, M. Crofoot, T. Fountain, D. Obando, A. Ortega, F. Kuemmeth, J. Mandel, G. Swenson, T. Lambert, B. Hirsch, and M. Wikelski. 2011. Tracking animal location and activity with an automated radio telemetry system in a tropical rainforest. Computer Journal 54: 1931-1948.

Kenny, J. S. 1966. Nest building in Phyllomedusa trinitatis Mertens. Caribbean Journal of Science 6: 15-22.

Key, G. E. and R. D. Woods. 1996. Spool-and-line studies on the behavioural ecology of rats (Rattus spp.) in the Galapagos Islands. Canadian Journal of Zoology 74: 733-737.

Laughlin, M. M., E. R. Olson, and J. G. Martin. 2017. Arboreal camera trapping expands Hyla versicolor complex (Hylidae) canopy use to new heights. Ecology 98: 2221-2223.

Long, Z. L., E. E. Prepas, and M. J. Lannoo. 2010. Assessment of intracoelomic implantation and waistband harness radiotransmitter attachment on wood frogs (Lithobates sylvaticus) and boreal toads (Anaxyrus boreas boreas). Herpetological Review 41: 315-318.

Madison, D. M., V. R. Titus, and V. S. Lamoureux. 2010. Movement patterns and radiotelemetry. Pp. 185-202 in C. K. Dodd Jr. (ed.), Amphibian Ecology and Conservation: a handbook of techniques. Oxford, New York. Oxford University Press.
Michaels, C. J., J. R. Downie and R. Campbell-Palmer. 2014. The importance of enrichment for advancing amphibian welfare and conservation goals: a review of a neglected topic. Amphibian and Reptile Conservation 8: 7-23.

Mullican, T. R. 1988. Telemetry and fluorescent radio pigments: a comparison. Journal of Wildlife Management 52: 627-631.

Murphy, J. C. 1997. Amphibians and Reptiles of Trinidad and Tobago. Malabar, Florida. Krieger Publishing Company.

Muths, E. 2003. A radio transmitter belt for small ranid frogs. Herpetological Review 34: 345-348.

Orlofske, S. A., K. L. Grayson, and W. A. Hopkins. 2009. The effects of fluorescent tracking powder on oxygen sonsumption in salamanders using either cutaneous or bimodal respiration. Copeia 2009: 623-627.

Parris, K. M., S. C. McCall, M. A. McCarthy, B. A. Minteer, K. Steele, S. Bekessy, and F. Medvecky. 2010. Assessing ethical trade-offs in ecological field studies. Journal of Applied Ecology 47: 227-234.

Rittenhouse, T., T. Altnether, and R. Semlitsch. 2006. Fluorescent powder pigments as a harmless tracking method for ambystomatids and ranids. Herpetological Review 37: 188-191.

Rowley, J. J. L. and R. A. Alford. 2007. Techniques for tracking amphibians: the effects of tag attachment, and harmonic direction finding versus radio telemetry. Amphibia-Reptilia 28: 367-376.

Schlacher, T. A. and S. Lucrezi. 2010. Compression of home ranges in ghost crabs on sandy beaches impacted by vehicle traffic. Marine Biology 157: 2467-2474.

Steinwald, M. C., B. J. Swanson, and P. M. Waser. 2006. Effects of spool-and-line tracking on small desert mammals. Southwestern Naturalist 51: 71-78.

Taylor, D. and L. Katahira. 1988. Radio telemetry as an aid in eradicating remnant feral goats. Wildlife Society Bulletin 16: 297-299.

Team, R. C. 2016. R: A language and environment for statistical computing. http://www.r-project.org/.

Waddell, E., A. Whitworth, and R. MacLeod. 2016. A first test of the thread bobbin tracking technique as a method for studying the ecology of herpetofauna in a tropical rainforest. Herpetological Conservation and Biology 11: $61-71$.

Wells, K. D. 2007. The Ecology and Behavior of Amphibians. Chicago. University of Chicago Press. 644 pp.

Editor: Jaime Bertoluci 
Appendix I. Pilot study 2015.

In a preliminary trial, we tested three tracking methods: 1) fluorescent powders (Rittenhouse et al. 2006); 2) nylon thread bobbins (Waddell et al. 2016); 3) radio- tags. Our results indicated that fluorescent dyes were not suitable for this species, causing individuals to become immobile and dehydrated, at most moving a couple of meters within a 24 hour period, whereas the other two methods worked well and were therefore used in the study reported here. It was also found that water absorption could severely reduce the effectiveness of the bobbins, and we therefore wrapped them in cling film and duct tape in all later work. The fluorescent powders were obtained from Radiant Color, Richmond, California, as used by Rittenhouse et al. After observing frogs at the breeding pools, we applied dye powder by brush to the insides of the legs and to the dorsal surface posterior to the forelimbs, then released them to their perches on the branches of shrubs. The frogs were observed next morning: most had not moved at all, in contrast to normal behavior, and appeared lethargic, possibly dehydrated when picked up. It is unclear why these frogs responded so differently to dye marking compared to the wood frogs and spotted salamanders marked by Rittenhouse et al. Phyllomedusa frogs waterproof their skins using their hindlimbs to spread wax secretions from cutaneous glands (Blaylock et al. 1976), and it is possible that the dyes interfered in some way with this behavior.

This pilot study provided the principal author (EHZG) with experience of safe handling of the frogs, and of the quickest, least stressful method to attach the tracking devices. This experience allowed her to train the team who helped carry out the work in 2016.

Appendix II. UHF Beacon Transceiver.

This transceiver is designed using telemetry system to corporate UHF frequency of $869 \mathrm{MHz}$

Figure below is the block diagram of the transceiver.

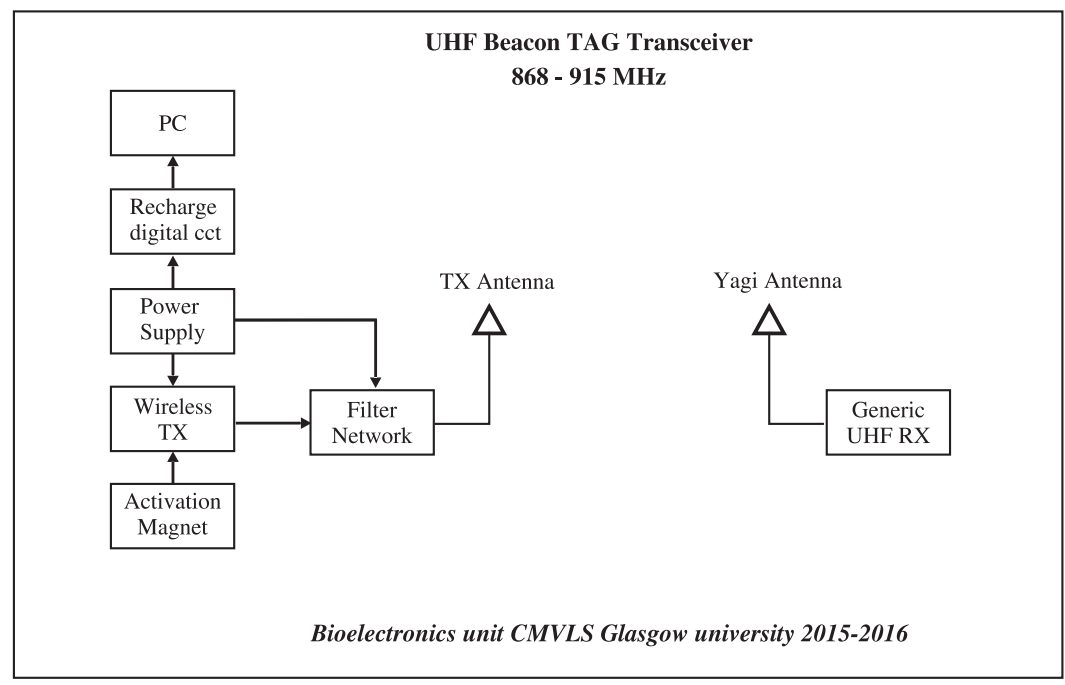

\section{Transmitter Hardware}

The transmitter side of the system comprises the following components: (1) very small ultra-low power wireless transmitter which is programmable with very few external components; the frequency band of 968-915 MHz can easily be programmed; it simply can be enabled or disabled by use of an activation magnet. (2) Power supply, which is a very small battery of $3.4 \mathrm{~V}$; this battery can be charged by connecting the recharge connection to a PC or laptop through digital interface. (3) Filter network and antenna are final stages of the transmission circuitry. 
The radio receiver side of the system comprises the following components: (1)Yagi antenna; (2) generic multi-channel radio receiver, which is capable of receiving signals for frequency between 868-915 MHz. If two beacon tags are provided, then the receiver must be pre-set to the two frequencies $(868.018 \mathrm{MHz}$ for channel 0 and $868.419 \mathrm{MHz}$ for channel 20).

\section{Using the Radio and Antenna to Detect the Beacon Tag}

When a beacon tag is activated it will transmit a very short burst on the appropriate radio channel at a repetition rate of $5 \mathrm{~s}$, which can be detected audibly. With the directional antenna connected to the radio, and that radio set to listen on the correct frequency, it should be possible to direction-find the device. When trying to simultaneously locate two tags it will be necessary to keep toggling the channel on which the radio is listening. With the two channels set in memory as V-B and V-A this toggling between channels can be achieved simply by pressing of the 2 VFO button. 